\title{
Size-selective grazing by a microflagellate on pelagic bacteria
}

\author{
A. Andersson ${ }^{1}$, U. Larsson ${ }^{2} \& \AA$. . Hagström ${ }^{1}$ \\ 'Department of Microbiology, University of Umeå, S-901 87 Umeå, Sweden \\ ${ }^{2}$ Askö Laboratory and Department of Zoology, University of Stockholm, S-106 91 Stockholm, Sweden
}

\begin{abstract}
The effect of microflagellate grazing on the size distribution of bacterial cells was studied using a heterotrophic microflagellate, Ochromonas sp., and mixed seawater bacteria in a 2-stage continuous culture. The flagellate grazed bacteria selectively, preferring cells larger than $0.2 \mu \mathrm{m}^{3}$. Median bacterial cell volume was reduced by $47 \%$, median cell length by $36 \%$ and median cell width by $8 \%$ compared to ungrazed control bacteria. An unexpected result was a drastic increase in numbers of bacteria in the 3 smallest size classes in the chemostat with flagellates. The size distribution of natural pelagic bacteria in the northern Baltic Sea was studied in spring and summer during 3 consecutive yr, 1982 to 1984 . Median bacterial cell volume decreased during summer, while phagotrophic microflagellates increased in abundance. We conclude that bacterial size distribution in the sea can be affected by size-selective grazing of heterotrophic microflagellates, and suggest that this explains the decrease in median bacterial volume during the summer.
\end{abstract}

\section{INTRODUCTION}

A number of recent investigations have emphasized the importance of heterotrophic microflagellates controlling bacterial numbers in the sea (Haas \& Webb 1979, Sieburth 1979, Fenchel 1982b, Sieburth \& Davis 1982, Davis \& Sieburth 1984, Andersen \& Fenchel 1985) and as an important link in the 'microbial loop' (Azam et al. 1983) transferring bacterial production up the food web.

Hitherto most interest has been focused on the quantitative aspects of flagellate food intake, while little is known about particle size selection and food composition. Heterotrophic microflagellates are taxonomically a very heterogeneous group of organisms, having in common their size and phagotrophic predation on bacteria. It is therefore logical to expect that the effect of flagellate predation on the prey population will differ depending on the species or species assemblage involved. Two main types of particle interception have been distinguished among heterotrophic microflagellates: filter feeding and interception feeding. The latter depends on a direct impact with the food particles in the water current generated by flagellar beats. The minimum size of the particles collected by filter feeders will depend on the free space between the pseudopodia, while for interception feeders it will be related to physical factors depending on the relative size of the predators and the food particles. Based on these theoretical considerations, Fenchel (1982a) postulated that larger bacterial cells would be preferentially grazed by interception-feeding microflagellates. Indirect evidence that bacteriovores preferentially exploit the larger bacterial cells was presented by Ammerman et al. (1984). These authors show that bacteria in 'sea-water cultures', (bacteria grown on filtered sea water in the absence of predators) increase their mean cell volume by a factor of 2.5 compared to the cell size of the bacterial community used as inoculum.

The object of the present study was to investigate whether or not an interception feeding Chrysomonad flagellate, Ochromonas sp., is size selective when grazing mixed sea-water bacteria. The experimental results are used to infer size-selective grazing by bacteriovores as one factor responsible for natural annual variations in bacterial size distributions.

\section{MATERIAL AND METHODS}

Grazing experiment. A 2-stage chemostat was set up to allow analysis of the effect of flagellate grazing on a steady-state culture of bacteria (Fig. 1). A common heterotrophic microflagellate, Ochromonas sp., iso- 


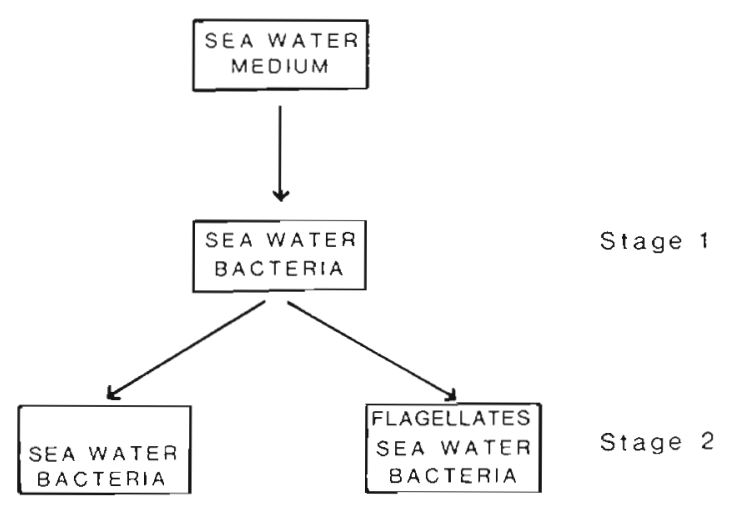

Fig. 1 Flow scheme for the 2-stage chemostat. In the first stage of the chemostat sea-water bacteria were grown in autoclaved sea water with a dilution rate of $0.03 \mathrm{~h}^{-1}$. The second stage had a dilution rate of $0.016 \mathrm{~h}^{-1}$ and consisted of 2 flasks, 1 control and 1 with flagellates added

lated from the northern Baltic Sea (Andersson et al 1985) and mixed bacteria in a seawater culture (Ammerman et al. 1984, Hagström et al. 1984) were used. Autoclaved seawater was used as a medium and the chemostat was kept at $18{ }^{\circ} \mathrm{C}$ in the dark. In the first stage of the chemostat, seawater bacteria were grown at a dilution rate of $0.03 \mathrm{~h}^{-1}$. These bacteria were then fed to the next stage of the chemostat, 2 flasks with a dilution rate of $0.016 \mathrm{~h}^{-1}$. Flagellates were introduced into one of these flasks, while the other served as control. Both stages of the chemostat were allowed to stabilize for $7 \mathrm{~d}$ before sampling started.

Field survey. The natural bacterial community was studied from 1982 to 1984 in the Norrby archipelago in the northern Baltic Sea $\left(63^{\circ} 31^{\prime} \mathrm{N}, 19^{\circ} 50^{\prime} \mathrm{E}\right)$. Water was collected with a Ruttner sampler every $2 \mathrm{~m}$, down to $14 \mathrm{~m}$ depth, and mixed.

Cell numbers and volume measurements. Four subsamples of $5 \mathrm{ml}$ were preserved for later analysis of cell counts and volumes. Samples were fixed in buffered (pH 8) formaldehyde (final concentration 1.5\%) and stained with ethidium bromide $\left(0.03 \mathrm{mg} \mathrm{m}^{-1}\right)$. A suitable volume was filtered through $0.2 \mu \mathrm{m}$ (bacteria) and $1.0 \mu \mathrm{m}$ (flagellates) filters (Nuclepore), mounted on slides and counted in an epifluorescence microscope (magnification $\times 982$ ). For bacteria, at least 10 viewing fields and/or 300 cells were counted on each slide. For flagellates, 30 microscopic fields were counted per slide, the cell numbers varying from 0 to 10 per field.

Cell size was determined from epifluorescence microscopy photographs (Zeiss M63 camera, Kodak technical pan film 2415). The negatives (magnification on the negative $\times 315$ ) were projected onto a graphics tablet (Tektronix 4956) and the bacterial cells were digitalized using a Tektronix 4051 computer: length (L) and width (W) were given for rods and spirals, diameter $(\mathrm{D}=\mathrm{L}=\mathrm{W})$ for coccoid bacteria. Cell vol- umes (V) were calculated as $\mathrm{V}=3.14\left[\left(\mathrm{~W}^{2} \mathrm{~L} / 4\right)-\left(\mathrm{W}^{3}\right)\right.$ 12)].

Statistical test. Since the samples were not normally distributed, differences in the size distribution of bacteria were tested by a median test (SAS Institute Inc. 1982, p. 206).

Bacterial growth. Bacterial production in mixed seawater samples (see above) was measured by the FDCmethod (1982 and 1983) (Hagström et al. 1979) and by ${ }^{3} \mathrm{H}$-thymidine uptake rates (1984) (Fuhrman \& Azam $1982)$. The bacterial growth rate $(\mu)$ was calculated as $\mu=\ln 2 / t_{d}$ where $t_{d}=$ doubling time of the bacteria (bacterial abundance/bacterial production). Bacterial biomass was converted to carbon equivalents assuming cell density $=1.1$, wet weight to carbon conversion $=0.22($ Bratback \& Dundas 1984).

\section{RESULTS}

\section{Selective grazing in continuous culture}

The effects of heterotrophic microflagellate grazing on the bacterial size distribution was investigated in a 2-stage chemostat (Fig. 1). In the first stage $(D=0.03$ $\mathrm{h}^{-1}$ ) the bacteria reached a cell concentration of $1.2 \times 10^{6}$ cells $\mathrm{ml}^{-1}$. In the second stage $(\mathrm{D}=0.016 \mathrm{~h})$, the average concentration of bacteria in the control remained $1.2 \times 10^{6}$ cells ml $^{-1}$ (Fig. 2). In the chemostat with added flagellates bacterial numbers were

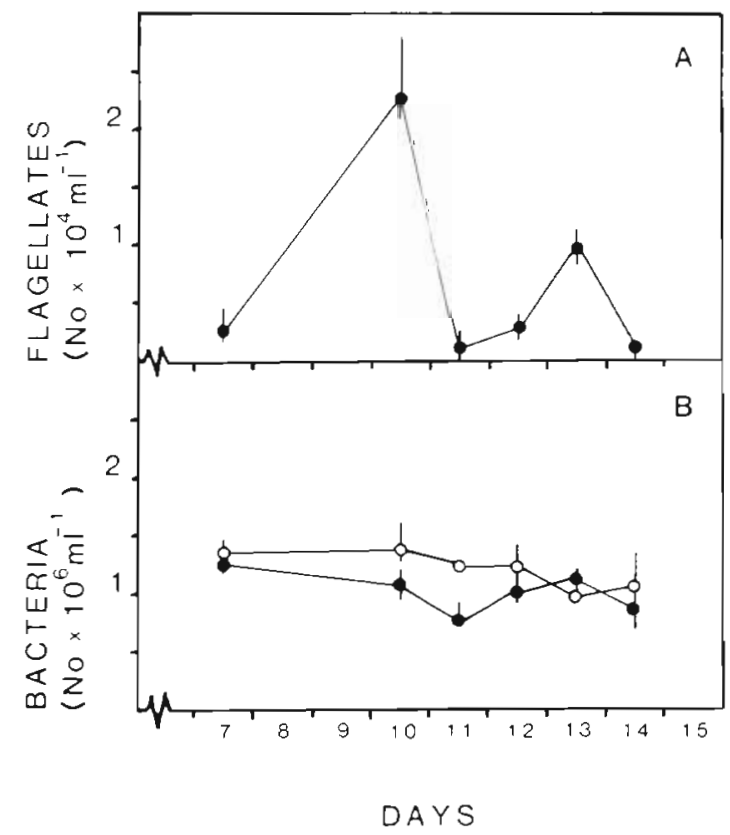

Fig. 2. Grazing experiment in continuous culture. Abundance of flagellates (A) and bacteria (B) versus time in the control (o), and in the flagellate treatment 
reduced to $1.0 \times 10^{6}$ cells $\mathrm{ml}^{-1}$. The consumed bacterial biomass $\left(2.0 \times 10^{5}\right.$ cells $\left.\mathrm{ml}^{-1}\right)$ supported an average concentration of $6.7 \times 10^{3}$ flagellates $\mathrm{ml}^{-1}$, however with large variations in flagellate numbers between the sampling occasions. To our knowledge there was not a chemostat problem. An explanation for the fluctuation in flagellate numbers might be the ability of the flagellate to attach temporarily to surfaces (Fenchel 1982a), giving rise to seeming variations in the flagellate concentration. Excluding the one very high flagellate number during the 10th day, on average 54 bacteria were consumed per flagellate produced. The average volume of the consumed bacteria was 0.32 $\mu \mathrm{m}^{3}$. Each new flagellate (average volume $10.1 \mu \mathrm{m}^{3}$ ) would require $4.6 \times 10^{-12} \mathrm{~g}$ of bacterial carbon assuming a flagellate carbon-to-volume ratio of $0.2 \mathrm{pgC}$ $\mu^{-3}$ (Holligan et al. 1984) and an assimilation efficiency of $44 \%$ (Caron et al. 1985). The bacterial biomass consumed by the flagellates was $4 \times 10^{-12} \mathrm{~g}$ $C$, thus most of the flagellate growth need was met.

The size of the bacteria decreased significantly when grazed by flagellates, on average from a median cell volume of $0.245 \mu^{3}$ in the control to $0.130 \mu \mathrm{m}^{3}$ in the chemostat with flagellates (Table 1, Fig. 3). Cell widths differed significantly on 3 out of 6 sampling occasions (Table 1). On average the median widths of grazed bacteria decreased $8 \%$. The reduction in cell volume was thus mostly due to a reduction by $36 \%$ in median cell length. About $70 \%$ of the bacteria in the size range 0.2 to $0.7 \mu^{3}$ were consumed by the flagellates (Fig. $4 \&$ 5). In the flagellate chemostat

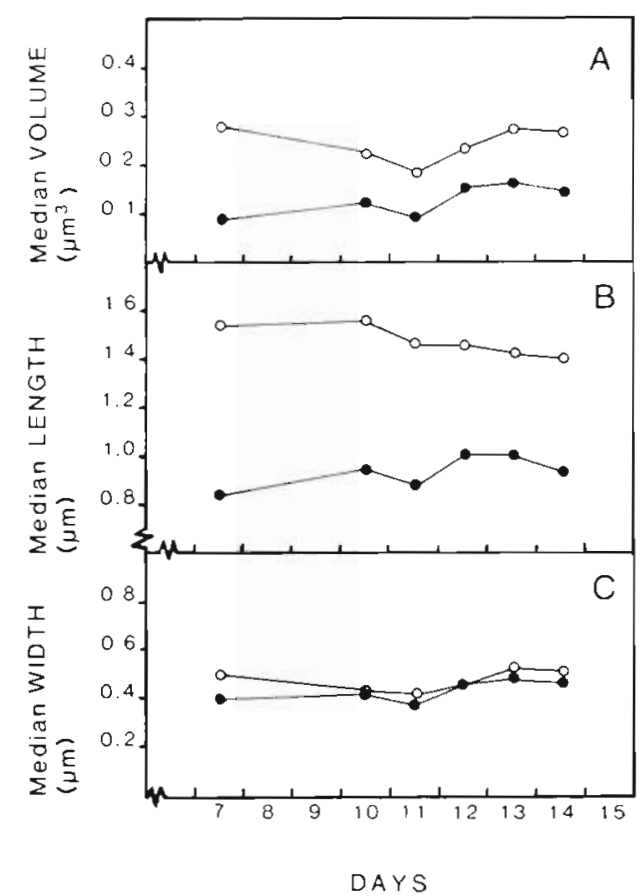

Fig. 3. The effect on bacterial cell size of flagellate grazing. Median cell volumes (A), lengths (B) and widths (C) versus time. (o) Control; (O) flagellate treatment

bacterial numbers in the 3 smallest size classes (less than $0.2 \mu \mathrm{m}^{3}$ ) increased (Fig. 4). In biomass this increase corresponded to $15 \%$ of the decrease in biomass in the larger size classes, while in numbers it corresponded to $70 \%$ of the consumed bacteria.

Table 1. Bacterial widths, lengths and volumes in the chemostat with $(+F)$ and without flagellates (Control). Differences between treatments tested by a median test. ${ }^{*} p<0.05 ; \cdots p<0.01 ; \cdots p<0.001$

\begin{tabular}{|c|c|c|c|c|c|c|c|c|}
\hline Day & Parameter & $\begin{array}{l}\text { No. obs. } \\
+\mathrm{F}\end{array}$ & $\begin{array}{l}\text { Median } \\
+F\end{array}$ & $\begin{array}{l}\text { Mean } \\
+F\end{array}$ & $\begin{array}{l}\text { No. obs. } \\
\text { Control }\end{array}$ & $\begin{array}{l}\text { Median } \\
\text { Control }\end{array}$ & $\begin{array}{l}\text { Mean } \\
\text { Control }\end{array}$ & $\begin{array}{c}\text { Median } \\
\text { test }\end{array}$ \\
\hline \multirow{3}{*}{7} & Width & 311 & 0.406 & 0.41 & 230 & 0.503 & 0.51 & $0.0001 \cdots$ \\
\hline & Length & 311 & 0.844 & 1.12 & 230 & 1.556 & 1.65 & $0.0001^{*} \cdots$ \\
\hline & Volume & 311 & 0.094 & 0.15 & 230 & 0.282 & 0.32 & $0.0001 \cdots$ \\
\hline \multirow{3}{*}{10} & Width & 214 & 0.431 & 0.45 & 270 & 0.440 & 0.45 & 0.099 \\
\hline & Length & 214 & 0.957 & 1.09 & 270 & 1.564 & 1.68 & $0.0001 \cdots$ \\
\hline & Volume & 214 & 0.123 & 0.16 & 270 & 0.228 & 0.25 & $0.0001 \cdots$ \\
\hline \multirow{3}{*}{11} & Width & 152 & 0.382 & 0.39 & 214 & 0.423 & 0.43 & $0.0003^{\cdots}$ \\
\hline & Length & 152 & 0.895 & 1.09 & 214 & 1.471 & 1.60 & $0.0001 \cdots$ \\
\hline & Volume & 152 & 0.095 & 0.12 & 214 & 0.188 & 0.22 & $0.0001 \cdots$ \\
\hline \multirow{3}{*}{12} & Width & 218 & 0.472 & 0.48 & 165 & 0.462 & 0.50 & 0.813 \\
\hline & Length & 218 & 1.027 & 1.14 & 165 & 1.463 & 1.71 & $0.0001 \cdots$ \\
\hline & Volume & 218 & 0.152 & 0.19 & 165 & 0.231 & 0.32 & $0.0001 \cdots$ \\
\hline \multirow{3}{*}{13} & Width & 144 & 0.496 & 0.50 & 189 & 0.532 & 0.55 & $0.0029^{\circ}$ \\
\hline & Length & 144 & 1.045 & 1.15 & 189 & 1.426 & 1.49 & $0.0001^{\cdots}$ \\
\hline & Volume & 144 & 0.165 & 0.20 & 189 & 0.274 & 0.32 & $0.0001 \cdots$ \\
\hline \multirow{3}{*}{14} & Width & 93 & 0.473 & 0.49 & 230 & 0.521 & 0.53 & $0.0004^{\cdots}$ \\
\hline & Length & 93 & 0.941 & 1.26 & 230 & 1.410 & 1.62 & $0.0001^{\cdots}$ \\
\hline & Volume & 93 & 0.148 & 0.21 & 230 & 0.265 & 0.32 & $0.0001^{\cdots}$ \\
\hline
\end{tabular}




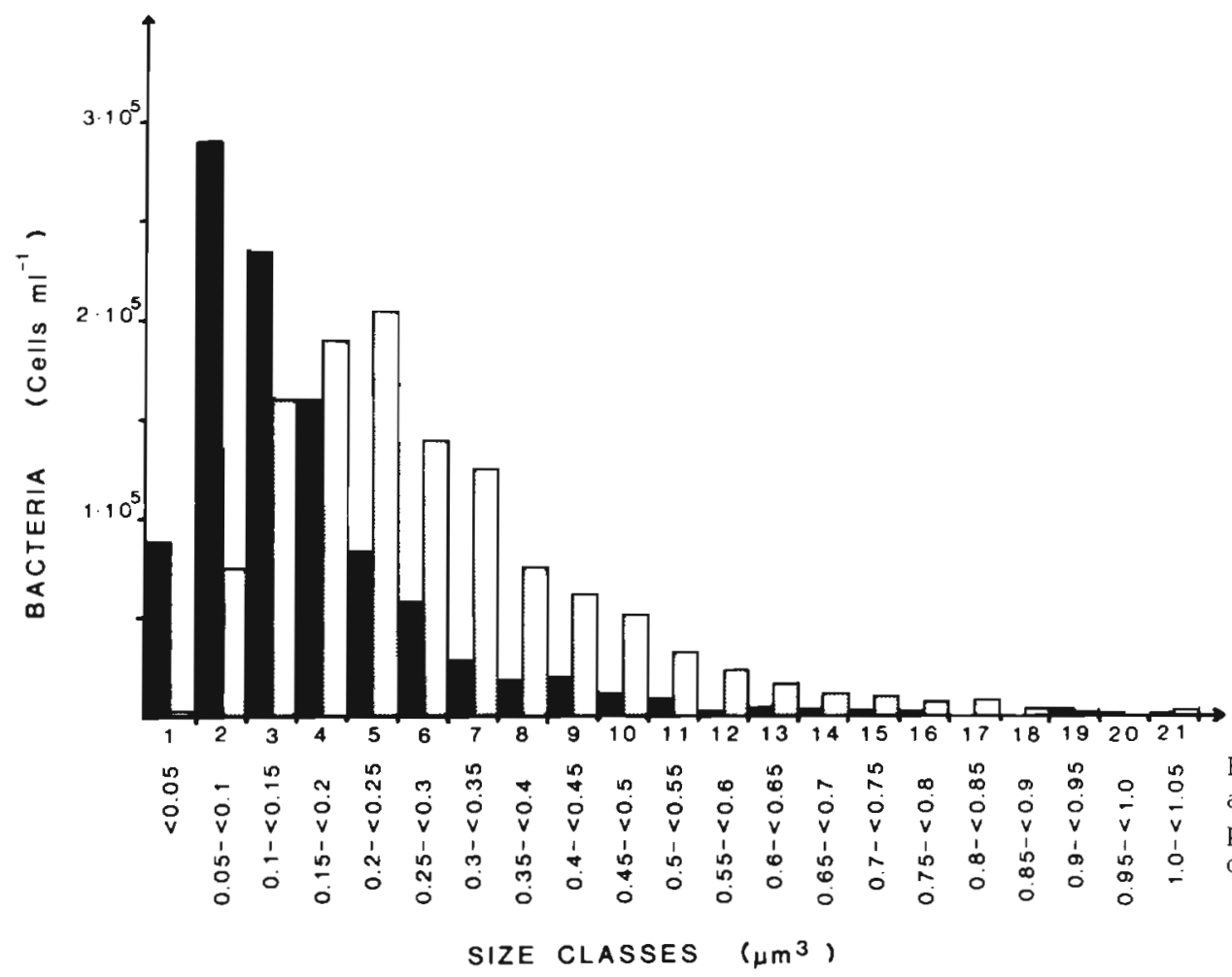

Fig. 4. Size distribution of bacterial cell volumes in the grazing experiment. Average for 6 sampling occasions. Stippled bars: control; filled bars: flagellate treatment

\section{Variation in size of bacteria in the sea}

The size distribution of a natural bacterial community in the Norrby archipelago was compared during spring (May) and summer (July) situations for $3 \mathrm{yr}$ (Fig. 6). From spring to summer the water temperature increases on average by $8 \mathrm{C}^{\circ}$, and as can be expected the bacterial growth rate increases (by 37 to $62 \%$ ) (Fig. $6 \mathrm{C})$. Since we used different methods to measure bacterial production, (1982-1983: FDC method; 1984: ${ }^{3} \mathrm{H}$-thymidine method), absolute bacterial growth rates differ, but as we used the same method within a year relative changes between different years can be compared. A decrease in bacterial median cell volume (by 20 to $45 \%$ ) from May to July was observed (Fig. 6A). No general conclusion can be drawn on which tactor (length or width) caused most of the decrease in cell volume, since in 1982 the change in cell length was responsible for the July decrease, in 1983 both width and length contribute about equally to the change in volume, and in 1984 cell width was responsible for the July decrease (Fig. 6B)

\section{DISCUSSION}

Our results show that the heterotrophic microflagellate Ochromonas $\mathrm{sp}$. preferentially consumes large bacterial cells. Fenchel (1982a) argued, based on a theoretical model generated for spherical collectors, that the efficiency of interception is proportional to the square of the radius of the particles. There are reasons to believe that biological mechanisms also may be involved in this phenomenon although little is known about the mechanisms used by the flagellate to capture bacteria. Mirelman \& Kobiler (1981) have shown membrane proteins (lectins) in the amoeba Entamoeba histolytica suggested to be vital for phagocytosis. If similar attachment systems occur among the related flagellates, cell-surface properties of the bacteria may also be of importance in prey selection.

An unexpected result in our grazing experiment was the increase of small bacteria (in the size classes 1 to 3 , Fig. 4) in the chemostat with flagellates. We have 2 possible explanations. (1) Flagellate excretion, e.g. amino acids and inorganic nutrients (Andersson et al. 1985), would allow growth of small bacteria avoiding microflagellate grazing either due to their size or their cell-surface properties. (2) The small particles may have been faecal material or remains of ruptured flagellate cells, mistaken for bacteria in the counting procedure. At present, we do not know which of the 2 explanations is the most plausible. If the second explanation is valid, and the same phenomenon occurs in nature, this has bearing on the validity of bacterial counts and the ongoing discussion of dormant versus actively growing bacterial cells.

In the Norrby archipelago a natural bacterial com- 


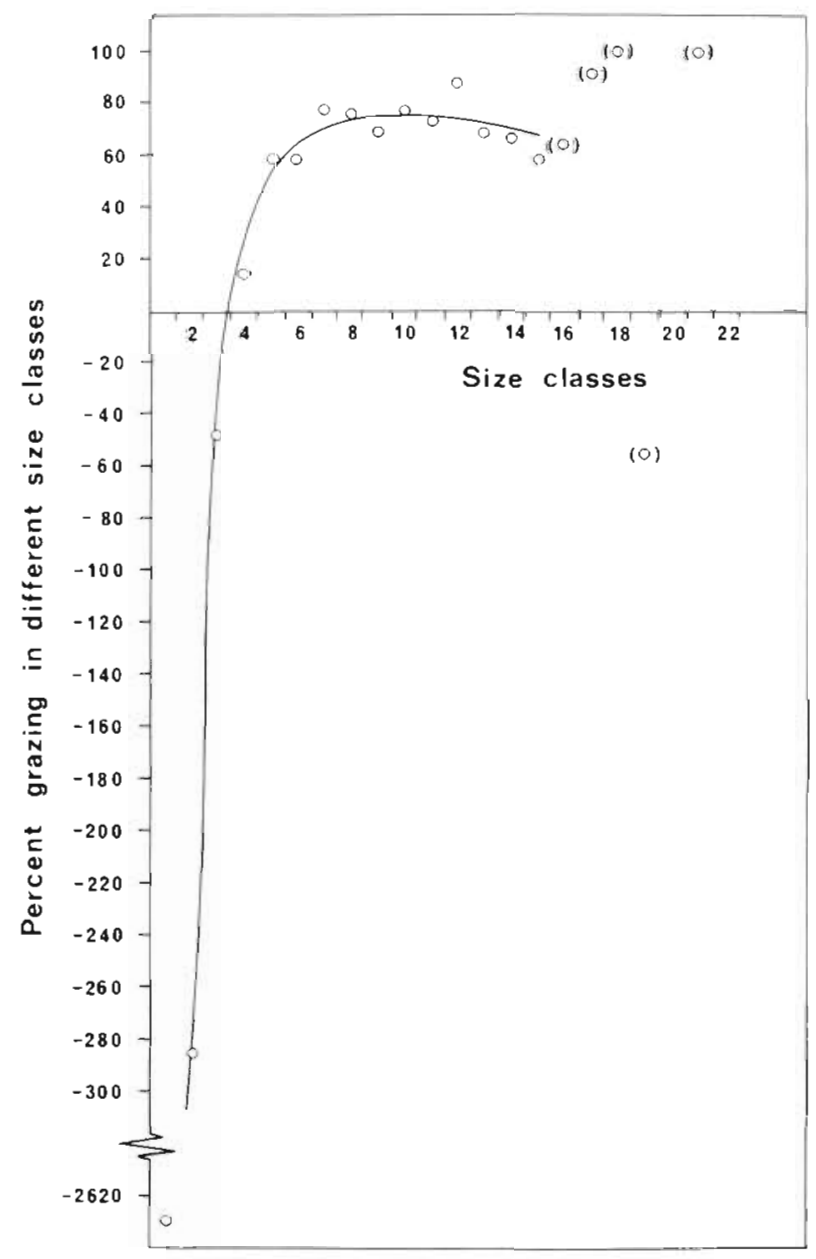

Fig. 5. Graph showing change in numbers within each size class between control and flagellate treatments. Positive values denote a decrease and negative values an increase in bacterial numbers in the flagellate culture compared to the control. Points are in parenthesis when the number of observations $<5$

munity was studied for 3 consecutive yr at the shift from spring (May) to summer (July). The summer situation with increased insolation and higher water temperatures gave rise to increased primary production allowing increased bacterial growth rate. As a general rule the cell volumes of fast-growing bacteria are larger than those of slow-growing bacteria (see below). Yet in our field data we find the opposite effect; the median cell size in July was reduced by $33 \%$ compared to May. The size distribution of a bacterial population is however affected by 2 main factors related to the physiology of bacterial growth working in opposite directions: substrate limitation and temperature.

The effects of substrate limitation are well known in enteric bacteria. In these bacteria, grown at $37^{\circ} \mathrm{C}$, the cell mass increases exponentially with increasing growth rate. When shifted from a poor medium (doubling time $5 \mathrm{~h}$ ) to a rich medium (doubling time $0.4 \mathrm{~h}$ )

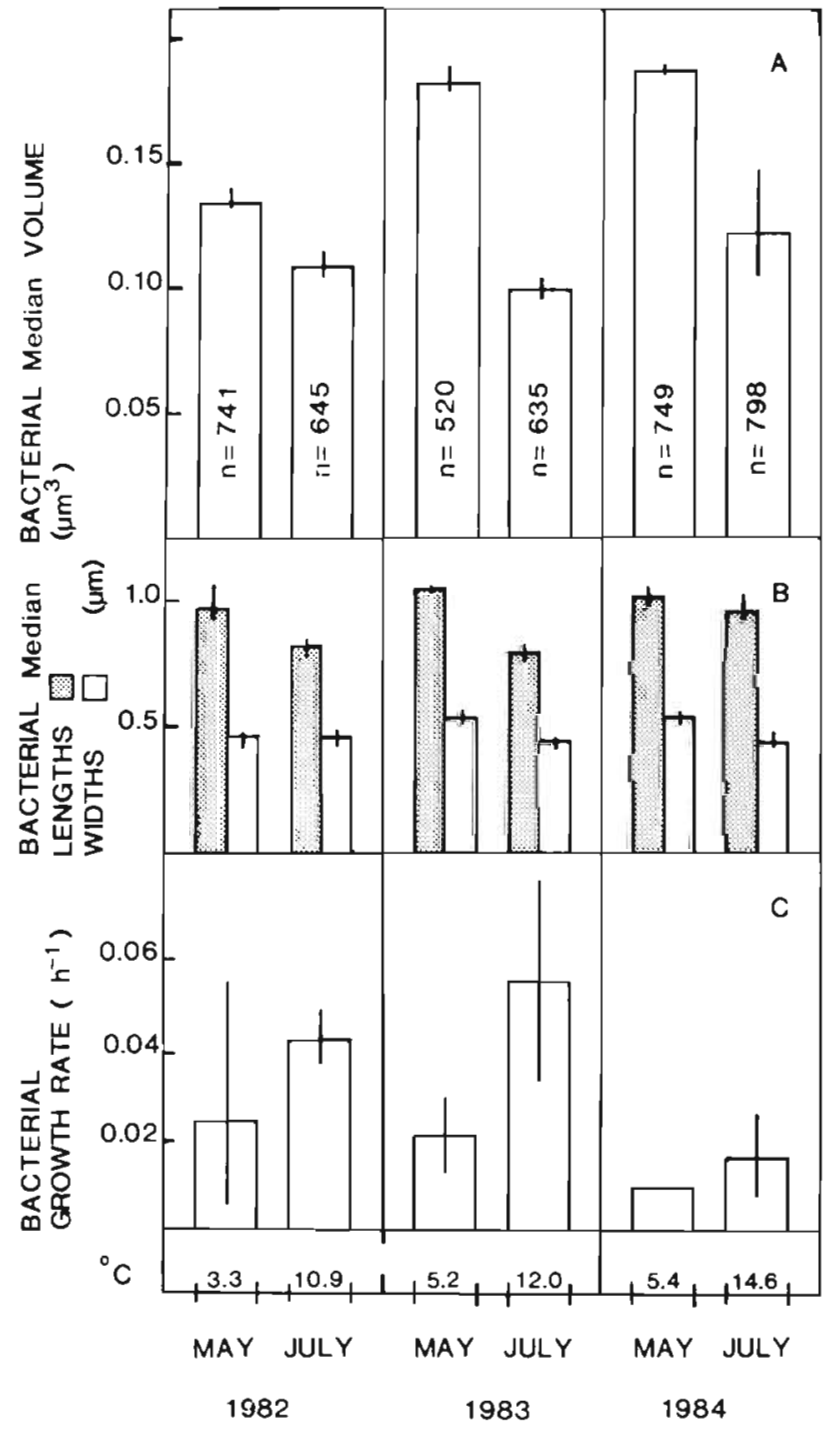

Fig. 6. Bacterial community in the Norrby archipelago, studied during spring (May) and summer (Jul), 1982 to 1984. (A) Median cell volume; (B) median cell lengths and widths; (C) growth rate of the bacterial population. Two to 3 measurements $\mathrm{mo}^{-1}$ were made; for each bar maximum and minimum median values are given. Figures in bottom panel denote mean water temperature in trophogenic layer (0 to $14 \mathrm{~m}$ )

the cell mass is increased by a factor of 4.8 (Maaløe \& Kjeldgaard 1966). The increase in volume is to a high degree caused by the increase of the protein-synthesizing system (PSS), which alone can account for $40 \%$ of the mass increase (Ingraham et al. 1983 p. 291). For bacteria growing in the above-quoted medium the size of the PSS, e.g. the number of ribosomes that are active in protein synthesis, is limiting for growth (Goldberger 1980 , p. 519). For very slow-growing, carbon-starved cells this relation is less clear since the overall efficiency of the ribosomes decreases (Goldberger 1980, p.520) and RNA is overproduced (Koch 1971). However, for mixed marine bacteria grown in continuous 
culture at growth rates found in situ, the relation for non-starved enteric bacteria holds true so that increasing growth rate results in increasing cell volumes (Larsson \& Hagström 1982). Assuming that the relation $\mathrm{V}=2.40 \mu+0.07(\mathrm{~V}=$ cell volume, $\mu=$ growth rate, $\mathrm{n}=4, \mathrm{r}=0.98$ ), derived from data in Larsson \& Hag ström (1982), is valid in nature the expected increase in mean cell volume from spring to summer due to the increased growth rate would be $26 \%$.

The effect of temperature on bacterial cell size has been studied on bacteria from the Baltic Sea. Bacteria forced, in a chemostat, to grow at the same growth rate but at different temperatures decrease in volume with increasing temperatures (Hagström \& Larsson 1984). An explanation to this might be that as long as the bacteria grow below their temperature optimum the cells compensate a reduced PSS efficiency, due to low temperatures, with more ribosomes. As a result of this the cells would become larger. Using the relation $\mathrm{V}=-0.016 \mathrm{t}+0.53(\mathrm{~V}=$ cell volume, $\mathrm{t}=$ temperature, $\left.{ }^{\circ} \mathrm{C}, \mathrm{n}=4, \mathrm{r}=-0.93\right)$, derived from data in Hagström \& Larsson (1984), the increase in water temperature of about $8 \mathrm{C}^{\circ}$ from May to July would make the bacterial cells $27 \%$ smaller.

Thus the net effect on bacterial cell volume of better substrate and increased temperature during the summer upshift would be almost zero. During 1984 we observed a $20 \%$ increase in number of phagotrophic flagellates from May to July (measured by the most probable number technique, data not shown). The observed decrease in the bacterial cell volume may therefore be interpreted as the effect of size-selective grazing by bacteriovores.

We regard the microflagellate in the chemostat experiment to be a model organism for microflagellates in the sea, and hence we believe that flagellates in this size range can affect the size distribution of bacterial cells in a similar way as we observed in the chemostat. Ammerman et al. (1984) have suggested that predation may control the size distribution of bacteria in the sea. These authors observed larger bacterial cells when seawater bacteria were allowed to grow in filtered seawater without predators. It is also notable that in their data the relative amount of rods increased during exponential growth. This is in agreement with the result from the chemostat experiment, where we observed the effect of the flagellates mainly as a decrease of bacterial median cell length. However, our field data from the Norrby archipelago do not show a consistent pattern of reduction of either bacterial cell length or width, which weakens the argument that predation could be the single factor responsible for the decrease in median bacterial cell volume.

Size-selective grazing poses the problem of how bacteria can continue to multiply if the cells which are about to divide are the ones most likely to be consumed. However, in the grazing experiment we show that grazing never removes more than about $70 \%$ of the bacteria in any of the size classes. Furthermore, if the flagellates themselves are subject to predation by organisms with diurnal patterns, the predation pressure on bacteria becomes cyclic, and fast-growing bacteria can escape the predator (Fuhrman et al. 1985). Such unsynchronized oscillations in bacterial and flagellate abundances have been shown by Andersen $\&$ Fenchel (1985).

In conclusion we have demonstrated size-selective grazing by a Chrysomonad microflagellate capable of reducing the median cell size of mixed seawater bacteria grown in continuous culture by $47 \%$, from 0.245 to $0.130 \mathrm{\mu m}^{3}$. Field data from the northern Baltic Sea show a decrease in the median bacterial cell volume at the shift from spring to summer, which cannot be explained solely by the growth physiology of bacteria. We believe that a significant part of the decrease may be explained by size-selective predation on the bacteria by bacteriovores similar in size to the flagellate used in the laboratory experiment.

Acknowledgements. We thank Prof. Glenn Björk and Dr. Ragnar Elmgren for critical comments on drafts of this manuscript; Mrs Eva-Lena Hörnfeldt and Mrs Stina Olofsson for technical assistance. This work was supported by grants from the Swedish Natural Science Research Council and from the Swedish National Environmental Protection Board

\section{LITERATURE CITED}

Ammerman, J. W., Fuhrman, J. A., Hagströrn, À., Azam, F. (1984). Bacterioplankton growth in seawater: I. Growth kinetics and cellular characteristics in seawater cultures. Mar. Ecol. Prog. Ser. 18: 31-39

Andersen, P., Fenchel, T. (1985). Bacteriovory by microheterotrophic flagellates in seawater samples. Limnol. Oceanogr. 30(1): 198-202

Andersson, A., Lee, C., Azam, F., Hagström, А. (1985) Release of aminoacids and inorganic nutrients by heterotrophic marine microflagellates. Mar Ecol. Prog. Ser 23: 99-106

Azam, F., Fenchel, T., Field, J. G., Gray, J. S., Mcyer-Reil, L A., Thingstad, F. (1983). The ecological role of watercolumn microbes in the sea. Mar. Ecol. Prog. Ser. 10 $257-263$

Bratbak, G., Dundas, I. (1984). Bacterial dry matter content and biomass estimations. Appl. environ. Microbiol. (48) 4 755-757

Caron, D. A., Goldman, J. C., Andersen, O. K., Dennett, M. R (1985). Nutrient cycling in a microflagellate food chain: II Population dynamics and carbon cycling. Mar. Ecol. Prog Ser. 24: 243-254

Davis, P. G., Sieburth, J. McN. (1984). Estuarine and oceanic microflagellate predation of actively growing bacteria: estimation by frequency of dividing-divided bacteria Mar. Ecol. Prog. Ser. 19: 237-246 
Fenchel, T (1982a). Ecology of heterotrophic microflagellates. I. Some important forms and their functional morphology. Mar. Ecol. Prog. Ser. 8: 211-223

Fenchel, T (1982b). Ecology of heterotrophic microflagellates. IV. Quantitative occurrence and importance as bacterial consumers. Mar Ecol. Prog. Ser 9: 35-42

Fuhrman, J. A., Azam, F. (1982). Thymidine incorporation as a measure of heterotrophic bacterioplankton production in marine surface waters: Evaluation and field results. Mar. Biol. 66: 109-120

Fuhrman, J. A., Eppley, R. W., Hagström, Å, Azam, F. (1985). Diel variations in bacterioplankton, phytoplankton, and related parameters in the Southern California Bight. Mar. Ecol. Prog. Ser. 27: 9-20

Goldberger, R. F. (1980). Biological regulation and development. Vol. 1, Gene expression. Plenum Press, New York

Haas, L. W., Webb, K. L. (1979). Nutritional mode of several non-pigmented microflagellates from the York river estuary, Virginia. J. exp. mar. Biol. Ecol. 39: 125-134

Hagström, Å., Ammermann, J. W., Henrichs, S., Azam, F. (1984). Bacterioplankton growth in seawater: II. Organic matter utilization during steady-state growth in seawater cultures. Mar. Ecol. Prog. Ser. 18: 41-48

Hagström, Å., Larsson, U. (1984). Diel and seasonal variation in growth rates of pelagic bacteria. In: Hobbie, J., Williams, J. LeB. (ed.) Heterotrophic activity in the sea. Plenum Press, New York

Hagström, A., Larsson, U., Hörstedt, P., Normark, S. (1979). Frequency of dividing cells, a new approach to the determination of bacterial growth rates in aquatic environments. Appl. environ. Microbiol. 37(5): 805-812
Holligan, P. M., Harris, R. P., Newell, R. C, Harbour, D. S., Head, R. N., Linley, E. A. S., Lucas, M. I., Tranter, P. R. G., Weekley, C. M. (1984). Vertical distribution and partitioning of organic carbon in mixed, frontal and stratified waters of the English Channel. Mar Ecol. Prog. Ser. 14: $111-127$

Ingraham, J. L., Maaløe, O., Neidhardt, F. C. (1983). Growth of the bacterial cell. Sinauer Associates, Sunderland, Massachusetts

Koch, A. L. (1971). The adaptive responses of Escherichia coli to a feast and famine existence. Adv. microb. Physiol. 6 : $147-217$

Larsson, U., Hagström, A. (1982). Fractionated phytoplankton primary production, exudate release and bacterial production in a Baltic eutrophication gradient. Mar. Biol. 67: $57-70$

Mirelman, D., Kobiler, D. (1981). Adhesion properties of Entamoeba histolytica. Adhesion and microorganism pathogenicity. Pitman Medical, Tunbridge Wells (Ciba Foundation Symposium 80), p. 17-35

Maaloe, O., Kjeldgaard, N. O. (1966). Control of macromolecular synthesis. A study of DNA, RNA and protein synthesis in bacteria. W. A. Benjamin, New York

SAS Institute Inc. (1982). User's guide: statistics. SAS Institute, Cary, North Carolina

Sieburth, J. McN. (1979). Sea microbes. Oxford University Press, New York

Sieburth, J. MCN., Davis, P. G. (1982). The role of heterotrophic nanoplankton in the grazing and nurturing of planktonic bacteria in the Sargasso and Caribbean Seas. Ann. Inst. océanogr., Paris 58(S): 285-296 